
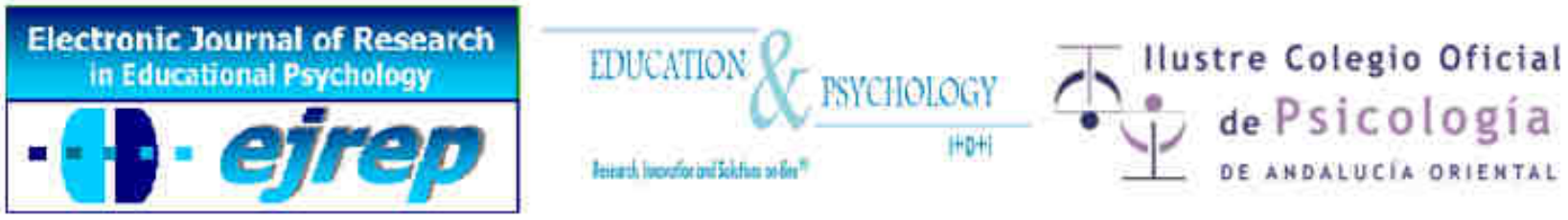

\title{
How are ICT used in the classroom? A study of teachers' beliefs and uses
}

\section{Carlos de Aldama ${ }^{1}$, Juan Ignacio Pozo ${ }^{1}$}

${ }^{1}$ School of Psychology . Autonomous University of Madrid, Madrid

\section{Spain}

Correspondence: Carlos de Aldama Sánchez. School of Psychology, Autonomous University of Madrid, Cantoblanco University Campus, 28049, Madrid, Spain. Tel.: + 349149787 50. E-mail: Carlos.dealdama@uam.es

(C) Education \& Psychology I+D+i and Ilustre Colegio Oficial de la Psicología de Andalucía Oriental (Spain) 


\begin{abstract}
Introduction. Several studies show that one of the essential factors in the way teachers use Information and Communication Technologies (ICT) in their lessons are the beliefs they hold regarding ICT as tools for teaching and learning. This study analyses the relationship between these beliefs and the way teachers use ICT in the classroom through design of a System of Categories for the Analysis of Beliefs about and Uses of ICT.

Method. We applied an open-ended questionnaire about beliefs and uses of ICT to 16 teachers of Child and Primary Education and collected 42 activities proposed by them where ICT were crucial. To analyse the answers, we designed a System of Categories for the Analysis of Beliefs about and Uses of ICT, based on three essential dimensions: what teachers said they taught, the psychological processes they activated in their students and the activities or tasks they proposed to achieve that learning.

Results. The results indicate that there is a wide gap between the beliefs teachers hold and the way they actually use ICT. While they said that ICT should be used to make learning more student-centred and to foster motivation, most of the activities proposed were aimed at onedirectional conveyance of contents, and were neither highly developed nor did they noticeably transform traditional ways of teaching.
\end{abstract}

Conclusions and Discussion. The paper concludes with a few reflections and suggestions about how ICT could really be integrated in the classroom based on a new learning culture.

Keywords: educational beliefs, pedagogical practices, teacher ICT use, technology integration 


\title{
Cómo se utilizan las TIC en el aula? Un estudio sobre las creencias y los usos
}

\begin{abstract}
Resumen
Introducción. Numerosos estudios muestran que un factor clave para explicar la forma en que los docentes usan las Tecnologías de la Información y Comunicación (TIC) en las aulas son las creencias que mantienen en relación con estos dispositivos como herramientas de enseñanza y aprendizaje. Este trabajo analiza la relación entre esas creencias y el uso que hacen los docentes de las TIC en el aula a través del diseño de un Sistema Categorial para el Análisis de las Creencias y Usos de las TIC.

Método: Aplicamos un cuestionario de preguntas abiertas sobre creencias y usos de las TIC a 16 docentes de Infantil y Primaria y analizamos 42 actividades propuestas por ellos donde las TIC tuvieran un papel relevante. Para analizar las respuestas, diseñamos un Sistema Categorial para el Análisis de las Creencias y Usos de las TIC, basado en tres dimensiones fundamentales: qué es lo que los profesores dicen enseñar, qué procesos psicológicos activan en sus estudiantes y las tareas o actividades que proponen para alcanzar sus objetivos de aprendizaje.
\end{abstract}

Resultados: Los resultados indican que existe una distancia considerable entre las creencias sostenidas por los profesores y el uso educativo que realmente hacen de las TIC. Mientras que los profesores afirman que las TIC son buenas herramientas para diseñar entornos de aprendizaje significativos centrados en el alumno, la mayoría de las actividades propuestas favorecen formas de enseñanza tradicionales centradas en el contenido.

Conclusiones y discusión: El artículo concluye con algunas reflexiones y sugerencias para una verdadera integración de las TIC en el aula basada en una nueva cultura del aprendizaje.

Palabras clave: creencias educativas, prácticas pedagógicas, uso de las TIC, integración tecnológica. 


\section{Introduction}

The study of ICT as tools for designing significant teaching and learning scenarios has been widely dealt with in recent years (Hadjithoma \& Karagiorgi, 2009; Monereo, 2004; Thompson, 2013). Despite the fact that there are opposing positions regarding the educational potential of ICT, usual discourse, whether political, educational or social (Coll \& Monereo, 2008; Ertmer, 2005), associates them to processes of change and improvement in educational quality. Coll \& Monereo (2008) highlight their qualities as tools for thinking and interthinking - instruments of symbolic nature offering unprecedented possibilities for accessing, finding, processing, conveying and sharing information.

However, most studies conducted to date on integrating ICT in classrooms systematically point out that merely introducing them into the classroom will not in itself guarantee educational transformation and improvement (Coll \& Monereo, 2008; Cuban, Kirpatrik \& Peck, 2001; Ertmer, 1999). Peggy Ertmer (1999) describes the obstacles to including ICT in the classroom as type I and type II barriers. Type I barriers are anything to do with the type of resources (equipment, time, training, support, etc.) to which the teacher has access. They are the first obstacle that needs to be overcome for true integration of ICT in the classroom. Type II barriers are less tangible, yet determinant, in the opinion of some authors (Fisher, Dwyer \&Yocam, 1996), and refer to the type of belief, often in the form of an "implicit theory" (Pozo et al., 2006), which the teacher holds with regard to teaching, learning and acquisition of knowledge. Below, we shall analyse in more detail the nature of these beliefs, reflect on different uses of ICT in the classroom, and finally, try to establish links between them.

\section{Educational beliefs held by teachers}

The concept of teachers' beliefs is a recurring topic in research into education (Nespor, 1987; Pajares, 1992). Although it is a difficult concept to define, there are many agreements regarding it. An initial approach would be the definition proposed by Richardson (2003), who defines beliefs as psychological representations, premises or propositions that an individual feels are true. They are relatively stable, develop based on personal experiences which compromise us emotionally, and help us see and understand the world in a given way (Pajares, 1992). 
Teachers' educational beliefs, psychology and intuitive pedagogy (Olson \& Bruner, 1996; Pozo et al., 2006) are implicit or explicit representations of individuals, objects and events, and the relationship among them within the educational context (Hermans, van Braak $\&$ van Keer, 2008). They develop over years of experience, ranging from life as a student at school (Richardson, 2003) to the different practices involved in professional performance as a teacher (Prestridge, 2012). This is why beliefs are stable and often resistant to change, though not impossible to modify. As noted by Prestridge (2012), in the context of change of teaching practice, professional development is successful when it promotes a change in beliefs (from teacher-centred to student-centred) by making them explicit and raising awareness, or by the teacher's reflection on his/her own practice (Schön, 1987).

Scientific literature has often classified educational beliefs along a continuum, with more traditional, mainly teacher-centred beliefs at one end, and more progressive, constructivist, student-centred beliefs at the other (Cox \& Webb, 2004; Kerlinger \& Kaya, 1959a, 1959b). In the former, the teacher is in charge of conveying clearly defined knowledge, and the quality of learning is measured by the student's capacity to acquire and reproduce this knowledge as faithfully as possible. In the latter case, the teacher mediates the learning process, which emerges from sharing dialogue and reflection with the students, and thus, knowledge is a progressive construction rather than a given.

Focusing more specifically on beliefs regarding the use of ICT, Ertmer $(1999,2005)$ classifies pedagogical beliefs about ICT as educational tools into three categories: 1) as a complement to the syllabus, for motivating students and developing their skills, 2) as support to the existing syllabus, where ICT would be an educational tool for teaching content, fostering cooperation among the different agents and promoting elaborate thinking, and 3) as tools fostering the emergence of a new syllabus adapted to the demands of the twenty-first century, where the student must change the way he learns. Similarly, Prestridge (2012) distinguishes four pedagogical beliefs regarding the use of ICT as educational tools: 1) to develop technical skills for using the device (using mouse, keyboard, interactive whiteboard, etc); 2) to perform functional activities (such as using a text processor), 3) to suggest tasks that extend and enrich the existing syllabus, and 4) to promote and explore new areas of teaching and learning. In the same vein, Mama and Hennessy (2013) suggest a similar classification, but add a belief type ("subversive") which includes the fear that ICT often produce in teachers. 
Uses of ICT in the classroom

A number of definitions, classifications and typologies have been developed within the context of educational use of ICT (Tondeur, van Braak and Valcke, 2007). For example, Prestridge (2012) conducted a study using the "Digital Age Learning Matrix" designed by Starkey (2009) where the author compared possible uses of ICT (accessing, presenting, processing, playing and communicating information) and learning levels promoted, which were, from least to most complex, doing, thinking about connections, thinking about concepts, criticising and evaluating, creating knowledge and sharing knowledge. Tondeur van Braak and Valcke (2007) conducted a factorial analysis on a sample of 352 primary school teachers, with the aim of developing a possible typology of uses at that educational level. The structure found revealed three factors: one referring to the use of ICT as information tools, another as learning tools, and a third focusing on developing basic skills (psychomotor). Coll and Monereo (2008) designed a typology of uses focusing on the teacher-learner-content interactive triangle, in an effort to overcome those focusing only on ICT potentialities and characteristics (Squires \& McDougall, 1994) or on major pedagogical and didactic issues (Salomon, Perkins \& Globerson, 1991). They also avoided neutral description (as in Twining, 2002), taking a firm stand from the socio-constructivist approach, which serves as reference for identifying the principal dimensions of educational practice.

We believe that the interactive triangle among teaching activity, contents of learning and student activity to acquire them is highly relevant. Therefore, as described below, we distinguish among three basic components present in any learning/teaching activity (Pozo, 2008): outcomes (what is learned), processes (the cognitive activity by means of which learning takes place, subdivided into two aspects, namely, the cognitive processes activated and the type of processing done with ICT, in a very similar vein to the uses suggested by Prestridge, 2012) and conditions (the teaching tasks or activities through which learning takes place), which are described in depth in the Methodology section.

Different uses of ICT have been identified through these different typologies, although in most cases their complexity is rather low. The famous study by Cuban et al. (2001) noted the little-developed educational uses to which teachers put ICT, even when almost complete 
technological infrastructure is available to them. The authors note that practice was characterised by simple use of ICT based on text processing and as a support to their lectures. These uses seemed to foster the conservation of traditional teaching models rather than their transformation.

More recently, Sigalés, Mominó, Meneses and Badia (2008) wrote an exhaustive report about the integration of internet in education in Spain. They say, "When teachers use ICT, it is primarily to convey contents and guide student learning. And when students use ICT, it is primarily to access contents and produce documents with content. Clearly, when teachers and students use ICT in class, it is usually content-related, making use mainly of information technologies, and to a much lesser extent, making use of communication technologies and the recently named learning technologies" (p.175). It seems that the oftmentioned technological revolution barely manages to break through the walls of schools (Coll \& Monereo, 2008). Can teachers' educational beliefs provide any clues to the reason for this?

Teachers' educational beliefs and how they relate to the use of ICT in the classroom

Ertmer (2005) believes that once extrinsic barriers (technological infrastructure, technical support, etc.) have been overcome, teachers' beliefs are a key factor for integrating ICT in the classroom. Many papers report a positive relationship between constructivist conceptions and the active use of technology (Ertmer, Ottenbreit-Leftwich, Sadik, Sendurur \& Sendurur, 2012; Hermans, Tondeur, van Braak \& Valcke, 2008; Kim, Kim, Lee, Spector \& DeMeester, 2013; Niederhauser \& Stoddart, 2001). For example, Cox and Webb (2004) analysed teachers' perceptions of ICT during the teaching process, based on the instructional/constructivist model, and conclude that constructivist stances favoured the use of ICT in the classroom. In the same vein, Sang, Valcke, van Braak and Tondeur (2010) found that teachers who held strong constructivist pedagogical beliefs were more receptive to integrating ICT in the classroom than teachers who did not hold these beliefs.

Otherwise, some studies have found inconsistencies between teachers' pedagogical beliefs and the activities they proposed (Liu, 2011; Zhao \& Cziko, 2001). Teo, Chai, Hung and Lee (2008) studied teachers in Singapore, and found a positive correlation between constructivist beliefs and both constructivist and traditional practices, although traditional beliefs were negatively correlated to constructivist practices. Tondeur, Hermans, van Braak 
and Valcke(2008) conducted a study on 574 primary school teachers and concluded that those who held strong beliefs, whether traditional or constructivist, used ICT in the classroom more often. Liu (2011) used questionnaires to analyse beliefs and practices with ICT in 1139 primary school teachers in Taiwan, concluding that although most teachers hold learnercentred beliefs, the way in which they integrate technology in the classroom diverges from constructivist practices.

The beliefs teachers hold and the way they use ICT seem to depend on certain variables. Several studies claim that these variables allow the different teacher approaches to ICT to be predICTed (Mumtaz, 2000; Peek et al., 2014; van Braak, 2001). Gender, for example, is one of the most frequently studied variables (Vekiri 2010; Volman, van Eck, Heemskerk \& Kuiper, 2005). Vekiri and Chronaki (2008) found that computer-mediated activities at school were central to male students much more often than to females. Similarly, males had much higher perceptions of self-efficacy. However, Iniesta-Bonillo, SánchezFernández and Schlesinger (2013) found no significant difference with regard to access and frequency of use, although they did find differences regarding their complexity. Females usually used ICT in more elaborate ways than males.

Age is another factor that has often been analysed (Drent \& Meelissen, 2008; Jamieson-Proctor, Watson, Finger, Grimbeek \& Burnett, 2007). Inan and Lowther (2010) found in a sample of 1382 teachers that age was negatively related to competence in the use of computers, making their integration in the classroom difficult, and possibly reflecting the fact that the digital gap is also a generation gap. However, these differences in uses do not imply radically different ways of learning between youths and adults (Margaryan, Littlejohn \&Vojt, 2011).

Howard, Chan and Caputi (2014) analysed different areas or disciplines of teacher specialisation and their relationship with educational beliefs, a key variable for predICTing integration of ICT in the classroom. The results showed that teachers of English as a foreign language considered ICT more important as educational tools than science teachers did. Tamim, Borokhovski, Abrami and Schmid (2011) conducted a second order meta-analysis of the research performed over the past 40 years on the integration of ICT in educational contexts, concluding that there are factors specific to each discipline which may condition that integration, e.g. the fact that mathematics often uses graphs (Hennessy, Ruthven \&Brindley, 
2005), sciences use visual representations (Cox \& Webb, 2004) and language and writing development in English (Silvernail \& Gritter, 2007).

Having situated the reader in the scenario of beliefs and educational uses of ICT, we shall now briefly describe the aims of our study.

\section{Study aims}

The aims of this study are to:

1.Design a System of Categories for the Analysis of Beliefs about and Uses of ICT which will allow us to look in depth at concrete aspects that other typologies do not reflect (Mama and Hennessy, 2013; Prestridge, 2012; van Braak, Tondeur and Valcke, 2004).

2. Identify teachers' educational beliefs regarding ICT as instruments for teaching and learning

3. Identify the ways in which teachers use ICT in the classroom context.

4. Determine whether there is consistency between teachers' educational beliefs regarding ITC and the ways in which they use them in the classroom

5. The final aim (though only exploratory, due to the sample size) is to analyse the influence that certain variables such as age (Drent \& Meelissen, 2008), gender (Volman et al., 2005), subjects taught (Howard et al., 2014) and educational level (Pelgrum, 2001) may have on educational beliefs and use of ITCs.

\section{Method}

\section{Participants}

We used a sample of 16 teachers of Child and Primary Education (12 female, 4 male, $\bar{X}=31.6$ years, S.D $=6.2$ ) that represents $47 \%$ of teacher's population from one school which has the following characteristics:

1) Newly built school (inaugurated in 2009).

2) Young teaching staff, trained and with little experience.

3) Interest in methodological and didactic innovations.

4) Decidedly focused on using ICT as learning tools: all classrooms had a video projector or an interactive whiteboard and at least three laptop or desktop computers. 
We thought that this school would be suitable as a reference regarding innovative practices in the use of ICT because its approaches to type I barriers (technological access and infrastructure) and type II barriers (teachers' educational beliefs) seemed to foster adequate integration of ICT in the classroom (Ertmer, 1999).

\section{Instrument for data collection}

In order to gather the information of interest, we prepared a questionnaire made up of open-ended questions, comprising two parts:

1. Initial question (Educational Beliefs): a general question about teachers' beliefs regarding ICT as instruments of change in teaching and learning processes.

2. Concrete activities (Uses of ICT): in this section we asked the teachers to describe in detail the three most important activities conducted in the classroom in which the teaching and learning processes were mediated by ICT. Specifically, we asked them to specify the teaching and learning aims proposed for the task, the roles played in it by teachers and students, and how they behaved when a difficulty arose during the course of the activity (regarding behaviour, learning, etc.).

\section{Procedure}

Part of research team arranged an appointment with the school principal to explain the aims of the study and the procedure. He requested his staff to respond the questionnaire and sent it to them via email. Teachers got around a week to answer it and afterwards they should to send back to the research team via email too. We chose this questionnaire as instrument for data collection because we thought it was the best procedure to let teachers think about their own experiences. In addition, we arranged interviews with some of them in order to clarify certain points of their answers to the questionnaire.

\section{Data analysis}

As mentioned above, the main aim of the study was to provide empirical evidence that would enable us to look more deeply into the relationship between teachers' educational beliefs and uses of ICT in the classroom. Our intention was to design an instrument for analysis which would allow the study of relevant aspects on which there is not much research to date. Based on previous studies of the research team in other areas (Casas, Montero \& Pozo, 2015; López-Iñíguez \& Pozo, submitted; Pozo \& Postigo, 2000), we developed this 
instrument paying attention to four main dimensions: 1) Learning Outcomes, focusing on the learning aim set by the teacher for students through an activity, 2) Information Processing, a category conceived for evaluating the cognitive demand of the proposed activities 3) Psychological Processes that the teacher intended to activate in the students, and 4) Learning Conditions, with reference to analysis of the context in which the ICT-mediated activity took place (Pozo, 2008)

The following chart summarises each category in the System of Categories for the Analysis of Beliefs about and Uses of ICT. 
Table 1. Learning Outcomes

A. Learning Outcomes

This category focuses on the learning aim set by the teacher for the students through an activity.

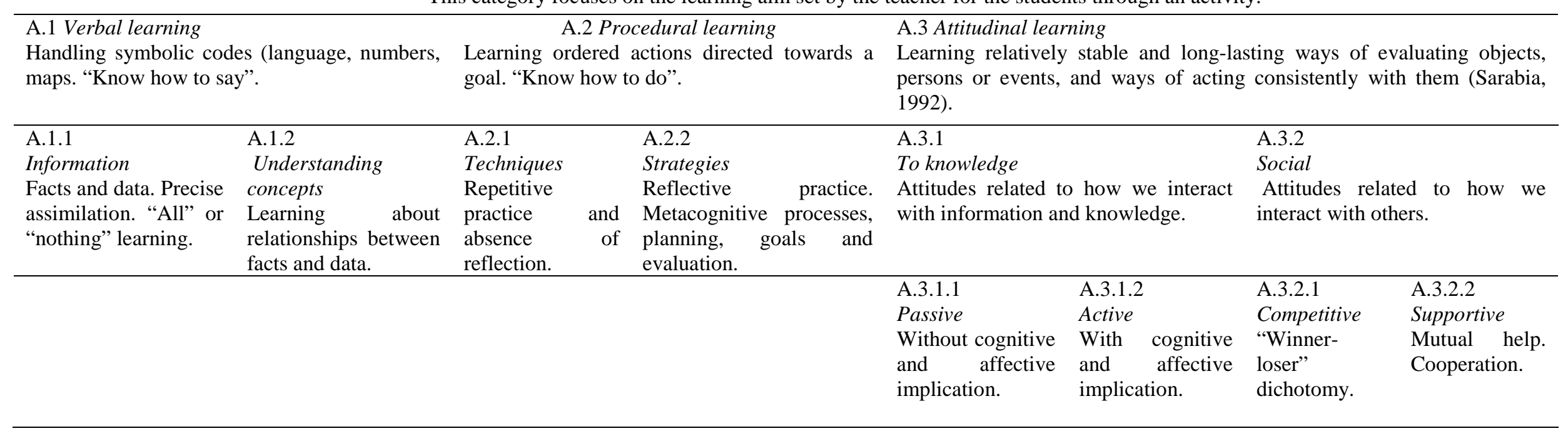


Table 2. Information Processing

B. Information Processing

This category evaluates the cognitive demand of the activities proposed, i.e. what kind of mental operations and cognitive resources students must put in motion to resolve the activity satisfactorily. We used the typology developed by Pozo and Postigo (2000).

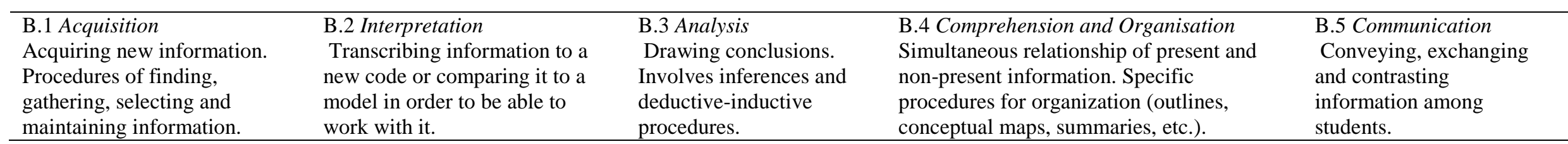

Table 3.Psychological Processes

$$
\text { B. Psychological Processes }
$$

This category analyses the psychological processes that teachers say they consider when they propose their activities.

\section{C.1 Memory \\ C.2 Attention \\ C.3 Motivation}

Storing and retrieving

information. Focusing cognitive

resources. Setting in motion cognitive and affective resources to perform a task.
C.4 Metacognitive Processes

Becoming aware of the various aspects of mental activity: planning, evaluation, defining goals, etc. 


\section{Learning conditions}

In this category we have grouped relevant aspects regarding "how" the ICT-mediated teaching and learning activity has been carried out.
Carlos de Aldama \& Juan Ignacio Pozo
D.1 ICT Support
"Hardware" through which the activity proposed

by the teacher materializes.

\section{D.2 What ICT are used for}

"What is done with ICT" in the classroom.

\section{D.3 Task complexity}

Level of difficulty of the task. Number of possible solutions, degree of uncertainty to be worked with or student manoeuvring leeway.

\section{D.4 Control of task}

Who is ultimately responsible during the course and development of the activity.

\section{D.5 Social organisation}

Distribution of students in the classroom and type of relationship between them, determined by the activity itself. student. student.

D.4.3 ICT
D.1.1 Projector/Interactive whiteboard

D.1.2 Portable computer

\section{D.2.1 Accessing information}

Following preset steps to make specific information available.

D.2.2 Presenting information

Showing given information considered interesting, whether it is

essential or complementary to the contributions of teacher and/or

D.2.3 Finding information

Accessing given sources to select and contrast specific information.

D.2.4 Gaming and entertainment

Fun and recreational aims.

D.2 5 Producing contents

Developing some kind of product.

D.3.1 Closed task

Single solution, low uncertainty and manoeuvring leeway for the

D.3.2 Open task

Multiple solutions, high uncertainty and student autonomy.

\section{D.4.1 Student}

D.4.2 Teacher

D.4.4 Shared

D.5.1 Individual

The activity is performed alone, with hardly any student-teacher interaction.

\section{D.5.2 Group}

The activity is performed in a group (two or more persons) without the need for cooperation among agents.

D.5.3 Cooperative

The activity is performed in a group (two or more persons), and requires cooperation to attain the aim of the task.

D.5.4 Undefined

Not enough information to determine it. 
Once the definite categories were defined, we analysed teachers' discourse. To do so we applied the categories we designed to each teachers' answers according to their educational beliefs and the 42 activities collected that represented the uses of ICT. This was done in duplicate, independently by two of the researchers on the team. Cohen's $\kappa$ was run to determine if there was agreement between them. According to Landis \& Koch (1977), there was a substantial and almost perfect agreement respectively, $\kappa=.750, p<0,01$ (in the case of educational beliefs sections) and $\kappa=.875, p<0,01$ (in the case of uses of ICT)

The results shown below correspond to the number/percentage of cases assigned to the different levels of each category (over a total 16 teachers for the Initial Question and 42 for Activities), taking into account that each case could only be assigned once (e.g. even if one teacher spoke several times within a single activity about an "active attitude" in the student, it would only be considered once within that activity). Except for some of the levels, such as attitude to knowledge, type of support or task complexity, the levels were not mutually exclusive. For example, a single task could demand both acquiring and interpreting information. Finally, the information gathered was processed using QDAMiner software. Results are presented below.

\section{Results}

\section{Teachers' educational beliefs}

The Fig.1 shows that over half the teachers (56.25\%) perceive ICT as good for motivating students, who must take responsibility for their own learning by acquiring an active attitude towards it (50\%). We illustrate it with the following example: T1: "[...] ICT are changing teaching and learning processes because there are many different possibilities and students feel attracted and motivated by them. In addition, ICT let students to become active entities and learn by experimentation"

Teachers point out that ICT have revolutionised the way of accessing information (50\%), making available to us whatever we are interested in, whenever we want it.. Aware of the demands of the Information Society, teachers see ICT as an opportunity to develop student learning strategies $(43.75 \%)$ through activities controlled by students themselves (37.5\%).The quotation presented below is an example: 
T2: “[...]with ICT students can self-assessment....and also they are useful for selflearning. Students are changing from being just consumers to become creators"

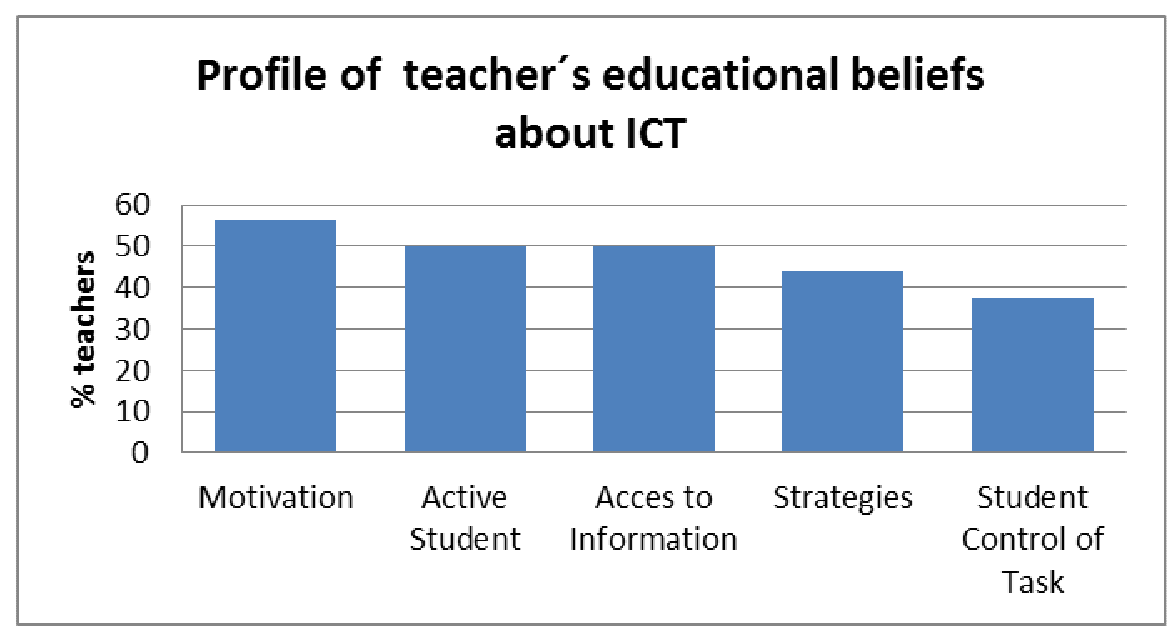

Figure 1. Profile of teachers' educational beliefs about ICT.

Teachers' uses of ICT

The Fig. 2 shows that most of the activities proposed by teachers involve acquiring information $(92.82 \%)$ in closed instructional contexts $(73.78 \%)$, as we showed in next example: T3: "One activity that I propose to my students is that they have to recognize in a map projected on a digital blackboard different elements (like rivers, jungles, deserts, etc)”. Similarly, teachers say they use ICT mainly for presenting information (57.12\%) in groups (52.36\%), where students have to assimilate the data and facts presented as faithfully as possible (61.9\%). See the following example: T4: "I use ICT to show videos, which aim is knowing different places. Later, I ask to the whole class what they have learnt." 


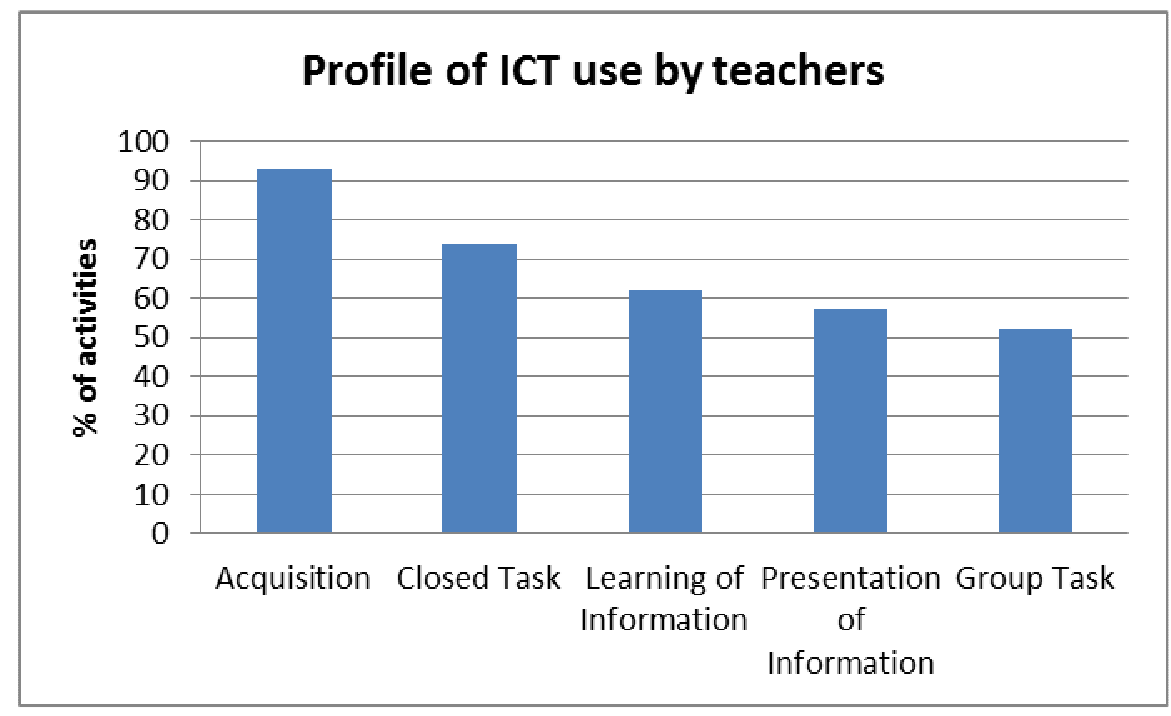

Figure 2.Profile of ICT use by teachers

\section{Conclusions about teachers'educational beliefs and uses of ICT}

Although teachers perceive the educational potential of ICT, showing favourable attitudes that promote their integration in the classroom, the fact is that in most cases, the activities proposed make little use of those opportunities. There are few situations in which the student really has to put into motion highly complex cognitive and affective resources, the tasks being limited to merely mechanical matters such as memorising or retrieving information. As noted by Cuban et al. (2001), the introduction of ICT to the classroom seems to lead to the reinforcement of existing educational practices rather than their transformation,

Below, we shall describe teachers' global discourse, focusing on variables where we have found significant differences in some aspect. These variables are "Subjects Taught" ("Generalist" teachers who teach subjects such as Maths, Language, or Social Studies and "Specialist" teachers who teach subjects such as Music, English as a foreign language, or Physical Education) and "Educational Phase" (teachers of Child Education or Primary Education).

Teachers' educational beliefs according to subjects taught

Table 5 shows the characteristics that teachers highlighted for ICT as educational tools, according to subjects taught. 
Table 5. Teachers' educational beliefs according to subjects taught

\begin{tabular}{llll}
\hline Generalists & Specialists & Chi-square & $\mathrm{P}$ value \\
$(\max =8)$ & $(\max =8)$ &
\end{tabular}

\begin{tabular}{|c|c|c|c|c|c|c|c|}
\hline \multirow{3}{*}{$\begin{array}{l}\text { Learning } \\
\text { outcomes }\end{array}$} & Techniques & & $0.0 \%$ & 1 & $12.5 \%$ & 1.067 & 0.302 \\
\hline & Strategies & 3 & $37.5 \%$ & 4 & $50.0 \%$ & 0.254 & 0.614 \\
\hline & Attitude to knowledge - active student & 4 & $50.0 \%$ & 4 & $50.0 \%$ & 0 & 1 \\
\hline $\begin{array}{l}\text { Psychological } \\
\text { processes }\end{array}$ & Motivation & 5 & $62.5 \%$ & 4 & $50.0 \%$ & 0.254 & 0.614 \\
\hline \multirow{2}{*}{$\begin{array}{l}\text { Learning } \\
\text { conditions }\end{array}$} & Accessing information & 3 & $37.5 \%$ & 5 & $62.5 \%$ & 1 & 0.317 \\
\hline & Student & 3 & $37.5 \%$ & 3 & $37.5 \%$ & 0 & 1 \\
\hline
\end{tabular}

The $\chi^{2}$ test at $95 \%$ confidence level shows that there is no significant difference between the discourse of Generalist and Specialist teachers. Many teachers highlight learning strategies (three of the eight Generalists and four of the eight Specialists) as the main goal of using ICT in the classroom, which contrasts with the almost complete absence of teachers who think of ITCs as tools for learning technical procedures (no Generalist and only one Specialist). The main goal involves an active student (four of the eight teachers in both cases), often responsible for controlling the task (three of the eight teachers in both cases), who uses ICT to access information (three and five of the eight teachers respectively). Motivation, in this case, takes on a highly relevant role (five of the eight Generalist teachers and four of the eight Specialist teachers).

\section{Teachers' use of ICT according to subjects taught}

Table 6 shows the characteristics of ICT-mediated activities proposed by teachers according to subjects taught.

Table 6. Teachers' uses of ICT according to subjects taught

\begin{tabular}{llll}
\hline $\begin{array}{lll}\text { Generalists } \\
(\max =23)\end{array}$ & $\begin{array}{l}\text { Specialists } \\
(\max =19)\end{array}$ & Chi-square & P value
\end{tabular}

\begin{tabular}{|c|c|c|c|c|c|c|c|}
\hline \multirow[t]{3}{*}{ Learning outcomes } & Information & 16 & $69.6 \%$ & 10 & $52.6 \%$ & 1.265 & 0.261 \\
\hline & Techniques & 9 & $39.1 \%$ & 6 & $31.6 \%$ & 0.258 & 0.611 \\
\hline & Strategies & 2 & $8.7 \%$ & 8 & $42.1 \%$ & 6.402 & 0.011 \\
\hline \multirow[t]{3}{*}{ Information processing } & Acquisition & 22 & $95.7 \%$ & 17 & $89.5 \%$ & 0.599 & 0.439 \\
\hline & Interpretation & 3 & $13.0 \%$ & 9 & $47.4 \%$ & 6.007 & 0.014 \\
\hline & Communication & 2 & $8.7 \%$ & 7 & $36.8 \%$ & 4.896 & 0.027 \\
\hline Psychological processes & Motivation & 1 & $4.3 \%$ & 1 & $5.3 \%$ & 0.019 & 0.89 \\
\hline
\end{tabular}




\begin{tabular}{llcrrrrr}
\hline & Metacognitive & 1 & $4.3 \%$ & 6 & $31.6 \%$ & 5.555 & $\mathbf{0 . 0 1 8}$ \\
\hline Learning conditions & Accessing information & & $0.0 \%$ & 4 & $21.1 \%$ & 5.352 & $\mathbf{0 . 0 2 1}$ \\
\cline { 2 - 7 } & Presenting information & 13 & $56.5 \%$ & 11 & $57.9 \%$ & 0.008 & 0.929 \\
\cline { 2 - 7 } & Closed & 21 & $91.3 \%$ & 10 & $52.6 \%$ & 8.05 & $\mathbf{0 . 0 0 5}$ \\
\cline { 2 - 7 } & Open & 2 & $8.7 \%$ & 8 & $42.1 \%$ & 6.402 & $\mathbf{0 . 0 1 1}$ \\
\cline { 2 - 7 } & Student & 5 & $21.7 \%$ & 8 & $42.1 \%$ & 2.019 & 0.155 \\
\cline { 2 - 7 } & Teacher & 6 & $26.1 \%$ & 5 & $26.3 \%$ & 0.041 & 0.153 \\
\cline { 2 - 7 } & ICT & 13 & $56.5 \%$ & 9 & $47.4 \%$ & 0.349 & 0.554 \\
\cline { 2 - 7 } & Group & & & & & 5 & 0.587 \\
\hline
\end{tabular}

The $\chi^{2}$ test at $95 \%$ confidence level shows that the activities proposed by the two groups differ significantly in learning outcomes, processing information, psychological processes and learning conditions. Most teachers design tasks whose aim is learning information (69.6\% of generalist proposals, and $52.6 \%$ of specialist proposals) through processes of acquisition (95.7\% and $89.5 \%$, respectively). They usually proposed close activities (91.3\% and 52.6\% respectively) based on presenting information (56.6\% and $57.9 \%$, respectively).

However, there are noticeable differences in the use of ICT by Generalist and Specialist teachers. The former design more frequently open tasks $(8.7 \%$ in Generalist teachers and $42.1 \%$ in Specialist teachers, $\left.\left(\chi^{2}(1.16)=6.402 ; p=0.011\right)\right)$ where learning outcomes are strategies $\left(8.7 \%\right.$ of Generalist proposals compared to $42.1 \%$ of Specialists $\left(\chi^{2}\right.$ $(1.16)=6.402 ; p=0.011))$ trough processes more demanding, like Interpretation $(13 \%$ of the Generalist teacher activities and $47.4 \%$ of Specialist teacher activities, $\left(\chi^{2}(1.16)=6.007 ; p=\right.$ $0.014)$ ) or Communication ( $8.7 \%$ and $36.8 \%$, respectively, $\left(\chi^{2}(1.16)=4.896 ; p=0.027\right)$ ). The latter proposed more closed activities $(91.3 \%$ of the activities of Generalist teachers and $52.6 \%$ of the activities of Specialist teachers, $\left.\left(\chi^{2}(1.16)=8.05 ; p=0.005\right)\right)$.

\section{Conclusions about teachers'educational beliefs and uses of ICT according to subjects taught}

Although there is a gap between what teachers think and what they say they put into practice, we should distinguish between groups. The gap is very wide in Generalist teachers. On the one hand, they conceive ICT as useful tools to learn strategies, where the student, motivated by using them, is active and in control of the task. On the other hand, they propose tasks that are mostly closed, mainly teacher-directed, where the main aim is to acquire information,

The gap is smaller in Specialist teachers. Their theoretical discourse, which is similar to that of Generalist teachers, is largely accompanied by consistent practices. The activities proposed often involve learning of strategies, which requires information to be processed 
differently from mere acquisition and taking into account metacognitive processes. Many tasks are open, where the student is in control, and often needs to cooperate with classmates.

In short, although there is a gap between what teachers believe and what they say they put into practice, in Specialist teachers the real model largely approaches the ideal model.

\section{Teachers' educational beliefs according to educational stage}

Table 7 shows the ICT characteristics highlighted as educational tools by teachers according to educational stage.

Table 7. Teachers' beliefs according to educational stage

\begin{tabular}{|c|c|c|c|c|c|c|c|}
\hline & & & $\begin{array}{l}\text { first cycle } \\
\text { school } \\
=8)\end{array}$ & $2=\mathrm{s}$ & $\begin{array}{l}\text { d third cycle } \\
\text { school } \\
=8)\end{array}$ & $\begin{array}{l}\text { Chi- } \\
\text { square }\end{array}$ & $\begin{array}{r}\mathrm{P} \\
\text { value }\end{array}$ \\
\hline \multirow{3}{*}{$\begin{array}{l}\text { Learning } \\
\text { outcomes }\end{array}$} & Techniques & & $0.0 \%$ & 1 & $12.5 \%$ & 1.067 & 0.302 \\
\hline & Strategies & 3 & $37.5 \%$ & 4 & $50.0 \%$ & 0.254 & 0.614 \\
\hline & $\begin{array}{l}\text { Attitude to } \\
\text { knowledge-active } \\
\text { student }\end{array}$ & 5 & $62.5 \%$ & 3 & $37.5 \%$ & 1 & 0.317 \\
\hline $\begin{array}{l}\text { Psychological } \\
\text { processes }\end{array}$ & Motivation & 4 & $50.0 \%$ & 5 & $62.5 \%$ & 0.254 & 0.614 \\
\hline \multirow[t]{2}{*}{$\begin{array}{l}\text { Learning } \\
\text { conditions }\end{array}$} & $\begin{array}{l}\text { Accessing } \\
\text { information }\end{array}$ & 1 & $12.5 \%$ & 7 & $87.5 \%$ & 9 & 0.003 \\
\hline & Student & 4 & $50.0 \%$ & 2 & $25.0 \%$ & 1.067 & 0.302 \\
\hline
\end{tabular}

The $\chi^{2}$ test at $95 \%$ confidence level shows one significant difference between the discourses of Child Education and First Cycle Primary School teachers on the one hand, and Second and Third Cycle Primary School teachers on the other, regarding the use of ICT. The latter say that ITCs have revolutionised the way of accessing information significantly more than the former $\left(\chi^{2}(1.16)=9,00 ; p=0.003\right)$.

In the rest of the dimensions, teachers' behaviour is very similar to that described above regarding the subjects taught: many of them desire acquiring strategies as learning outcome (three of the eight Child and First Cycle Primary School Teachers, and four of the eight Second and Third Cycle Primary School teachers), through activities where the student must be active (five and three of the eight teachers, respectively), taking control of the task thanks to the ICT (four and two of the eight teachers, respectively). In this case they also highlight the intrinsic capacity of ICT to motivate (four and five of the eight teachers, respectively). 


\section{Teachers' use of ICT according to educational stage}

Table 8 shows the characteristics of ICT-mediated activities proposed by teachers according to educational stage.

Table 8-Teachers' uses of ITC according to educational stage

\begin{tabular}{|c|c|c|c|c|c|c|c|}
\hline & & & $\begin{array}{l}\text { first cycle } \\
\text { chool } \\
\text { 22) }\end{array}$ & & $\begin{array}{l}\text { third cycle } \\
\text { chool } \\
20)\end{array}$ & $\begin{array}{l}\text { Chi- } \\
\text { square }\end{array}$ & $\begin{array}{r}\mathrm{P} \\
\text { value }\end{array}$ \\
\hline \multirow{4}{*}{$\begin{array}{l}\text { Learning } \\
\text { outcomes }\end{array}$} & Information & 13 & $59.1 \%$ & 13 & $65.0 \%$ & 0.155 & 0.694 \\
\hline & $\begin{array}{l}\text { Understanding } \\
\text { concepts }\end{array}$ & & $0.0 \%$ & 1 & $5.0 \%$ & 1.127 & 0.288 \\
\hline & Techniques & 8 & $36.4 \%$ & 7 & $35.0 \%$ & 0.008 & 0.927 \\
\hline & Strategies & 4 & $18.2 \%$ & 6 & $30.0 \%$ & 0.807 & 0.369 \\
\hline \multirow{2}{*}{$\begin{array}{l}\text { Information } \\
\text { processing }\end{array}$} & Acquisition & 21 & $95.5 \%$ & 18 & $90.0 \%$ & 0.47 & 0.493 \\
\hline & $\begin{array}{l}\text { Communicatio } \\
\mathrm{n}\end{array}$ & 2 & $9.1 \%$ & 7 & $35.0 \%$ & 4.177 & 0.041 \\
\hline \multirow[t]{12}{*}{$\begin{array}{l}\text { Learning } \\
\text { conditions }\end{array}$} & $\begin{array}{l}\text { Presenting } \\
\text { information }\end{array}$ & 13 & $59.1 \%$ & 11 & $55.0 \%$ & 0.072 & 0.789 \\
\hline & $\begin{array}{l}\text { Finding } \\
\text { information }\end{array}$ & 2 & $9.1 \%$ & 8 & $40.0 \%$ & 5.517 & 0.019 \\
\hline & Closed & 20 & $90.9 \%$ & 11 & $55.0 \%$ & 6.988 & 0.008 \\
\hline & Open & 2 & $9.1 \%$ & 8 & $40.0 \%$ & 5.517 & 0.019 \\
\hline & Student & 5 & $22.7 \%$ & 8 & $40.0 \%$ & 1.462 & 0.227 \\
\hline & Teacher & 9 & $40.9 \%$ & 7 & $35.0 \%$ & 0.155 & 0.694 \\
\hline & ICT & 8 & $36.4 \%$ & 3 & $15.0 \%$ & 2.473 & 0.116 \\
\hline & Shared control & 1 & $4.5 \%$ & 3 & $15.0 \%$ & 1.329 & 0.249 \\
\hline & Individual & 6 & $27.3 \%$ & 3 & $15.0 \%$ & 0.937 & 0.333 \\
\hline & Group & 13 & $59.1 \%$ & 9 & $45.0 \%$ & 0.834 & 0.361 \\
\hline & Cooperative & 2 & $9.1 \%$ & 4 & $20.0 \%$ & 1.018 & 0.313 \\
\hline & Undefined & 1 & $4.5 \%$ & 5 & $25.0 \%$ & 3.58 & 0.058 \\
\hline
\end{tabular}

The $\chi^{2}$ test at $95 \%$ confidence level shows that the activities proposed by the two groups differ significantly regarding processing information and learning conditions.

Learning outcomes show that in most cases teachers propose activities that foster learning information (59.1\% for Child and First Cycle Primary School teachers and 65\% for Second and Third Cycle Primary School teachers) and with regard to procedures, they mostly propose techniques rather than strategies.

With regard to processing information, most of the activities proposed by teachers require processes of acquiring information (95.5\% of tasks presented by teachers of Child and First Cycle Primary School and $90 \%$ of the tasks presented by Second and Third Cycle Primary School teachers). Nevertheless, the significant differences in this dimension appear in 
communication $\left(\chi^{2}(1.16)=4.177 ; p=0.041\right)$. While the former rarely design activities where the aim is to share the information acquired and/or prepared $(9.1 \%)$, in the latter, this

percentage is higher, at 35\%. However, when we apply the Fisher's exact statistical test correction this difference is not significant $(\mathrm{p}=0,062)$.

Regarding use of ICT, more than half the teachers' proposals use ICT for presenting information (59.1\% and 55\%, respectively). However, the significant differences between groups are found in finding information $\left(\chi^{2}(1.16)=5.517 ; p=0.019\right)(9.1 \%$ and $40 \%$, respectively). This result is consistent with what was found for complexity of the task, where there are significant differences for both closed tasks $(90.9 \%$ of the activities proposed by Child Education and First Cycle Primary School teachers, and 55\% of proposals from Second and Third Cycle teachers $\left.\left(\chi^{2}(1.16)=6.988 ; p=0.008\right)\right)$, and for open tasks $(9.1 \%$ and $40 \%$ respectively $\left.\left(\chi^{2}(1.16)=5.517 ; p=0.019\right)\right)$. In other words, the results seem to indicate that teachers of older children carry out activities in the classroom involving significantly more complex use of ICT by the students.

Conclusions about teachers'educational beliefs and uses of ICT according to educational stage

Again, there are major differences between what teachers think and what they say they do with ICT. They say they highlight students acquiring strategies through active role and taking responsibility for controlling the task. The ability to motivate would be the added value of the ICT, whose main use would be directed to accessing information. The second case, however is different. Most of the activities proposed demand acquiring information (rather than strategies) which is presented (rather than accessed). Although there are some open tasks, most of them are closed, which implies a reduction in learner control and active attitude. Motivation is rarely mentioned (no reference in Child Education or First Cycle Primary School, and 10\% in Second and Third Cycle Primary School). The following is a summary of the results. 


\begin{tabular}{|c|c|c|c|c|c|}
\hline \multirow{2}{*}{\begin{tabular}{c}
\multicolumn{1}{c}{$\begin{array}{c}\text { Subjects } \\
\text { taught }\end{array}$} \\
$\checkmark$ No \\
significant \\
difference
\end{tabular}} & $\begin{array}{l}\text { Educational } \\
\text { Stage }\end{array}$ & \multicolumn{2}{|c|}{ Subjects taught } & \multicolumn{2}{|c|}{ Educational stage } \\
\hline & $\begin{array}{l}\checkmark \text { 2nd and 3rd } \\
\text { Cycle Primary: } \\
\text { Accessing Info }\end{array}$ & Specialists & Generalists & $\begin{array}{c}\text { Child and 1st } \\
\text { Cycle } \\
\text { Primary } \\
\end{array}$ & $\begin{array}{l}\text { 2nd and 3rd } \\
\text { Cycle } \\
\text { Primary } \\
\end{array}$ \\
\hline & & $\begin{array}{l}\checkmark \text { Learning } \\
\text { outcome } \\
\checkmark \text { Processing } \\
\text { Info } \\
\checkmark \text { Psychological } \\
\text { processes } \\
\checkmark \text { Uses of ICT } \\
\checkmark \text { Complexity } \\
\text { of task } \\
\text { More elaborate }\end{array}$ & $\begin{array}{l}\checkmark \text { Learning outcome } \\
\checkmark \text { Processing Info } \\
\checkmark \text { Psychological processes } \\
\checkmark \text { Uses of ICT } \\
\checkmark \text { Complexity of task } \\
\text { Less elaborate }\end{array}$ & $\begin{array}{l}\checkmark \text { Processing } \\
\text { Info } \\
\checkmark \text { Uses of } \\
\text { ICT } \\
\checkmark \text { Complexity } \\
\text { of task } \\
\text { Less } \\
\text { elaborate }\end{array}$ & $\begin{array}{l}\checkmark \text { Processing } \\
\text { Info } \\
\checkmark \text { Uses of } \\
\text { ICT } \\
\checkmark \text { Complexity } \\
\text { of task } \\
\text { More } \\
\text { elaborate }\end{array}$ \\
\hline
\end{tabular}

\section{Discussion}

With regard to the first aim, it is worth noting that an interesting contribution of our study, along with the results obtained, is the design of the System of Categories for the Analysis of Beliefs about and Uses of ICT. We believe it is a useful, valuable tool, which will enable in-depth studies of relevant aspects of beliefs and uses of ICT, such as the learning outcomes it promotes or the type of information processing required. As described above, this system is an instrument for analysis which contributes different aspects not included in other available systems (Coll \& Monereo, 2008; Mama \& Hennessy, 2013; Prestridge, 2012; van Braaket al, 2004).

With regard to the following three aims of our study, the main purpose was to test whether there is consistency between teachers' educational beliefs about ICT and how they use them in the classroom. The results show that there is in fact a wide gap. While in most cases, beliefs involve elaborate conceptions of ICT as educational tools, the practices carried out reflect uses that are not highly transformative. Teachers think of ICT as instruments providing novel ways of relating to information, to others and to oneself. Access, speed, ability to modify and produce information, as well as the possibility of being in continuous contact with others, are characteristics that teachers recognise and value in ICT (Coll \&Monereo, 2008). Nevertheless, the use they make of them does not indicate the same. ICTmediated educational practice, as noted by Liu (2011), reflects teacher-centred activity, with few demands regarding processing information, and where the student, once again, fulfils a 
role as a passive consumer. This trend is similar to that found in other studies of teachers' conceptions of teaching and learning. Teachers still tend to focus more on the transmission of knowledge established by themselves than on construction of knowledge by students (LópezIñiguez, Pozo \&de Dios, 2014; Olson and Bruner, 1996; Pozo et al., 2006). However, due to the sample size is very small, these results have to be interpret carefully. Future researches should pay attention at this point.

With regard to the fifth aim, although it is true that there is usually a gap between beliefs and uses, we found that some specialist teachers and teachers of second and third stage of primary school proposed activities that made the most of ICT potential: interactivity, autonomy, reflection, managing uncertainty and metacognition were just some of the processes they put into motion in their classroom practice. These teachers are the example that shows that ICT can be extraordinarily powerful tools for promoting quality educational practices, where the aim is not merely to convey established knowledge, but rather to construct true knowledge. The new learning culture requires dialogue between teachers and students which transcends the limits of the classroom to include the new scenarios opened up by ICT. Specifically, information management through ICT should help promote three essential changes in ways of teaching and learning:

1. Change from realist epistemology based on one-directional conveyance of "true", closed knowledge to joint management of knowledge, understood as collective negotiation of shared meanings.

2. Change from one-directional management of knowledge (monological) to multi-directional (dialogical), where the teacher is no longer a mere dispenser of established knowledge, but becomes a mediator in reflective dialogue.

3. Change from knowledge based on a single system of representation (written or oral language) to dynamic integration of multiple systems. This involves simultaneous management of multiple codes which make the teaching and learning processes more complex.

However, as noted throughout this paper, the mere introduction of technological devices into classrooms does not ensure change. We need to promote spaces for reflection in which to re-think the role that teachers and students play in society and education in the twenty-first century, where conceptions and beliefs about teaching and learning can be reformulated (Pozo et al., 2006). From a traditional conception based on the conveyance of 
established knowledge, the role of ICT is limited to a change in the support of teaching practice. However, based on conceptions where knowledge is not only an end in itself, but also a means for constructing a complex world view nurtured by contact with multiple voices and standpoints, ICT are exceptional tools for constructing a new learning culture. Future researches should analyse how all those processes are developed in specific contexts.

\section{Acknowledgement}

The Spanish Ministry of Economy and Competitiveness has supported this research through the Project EDU2013-47593-C2-1-P.

\section{References}

Casas-Mas, A., Montero, I. \& Pozo, J.I. (2015). El discurso sobre la práctica de un guitarrista de jazz semi-profesional: Estudio de caso de aprendizaje musical constructivo. International Association for the Study of Popular Music Journal, 5 (1) http://www.iaspmjournal.net/index.php/IASPM_Journal/article/view/722 doi: $10.5429 / 2079-3871(2015) v 5 i 1.5$ es

Coll, C. \& Monereo, C. (Eds.). (2008). Psicología de la educación virtual. Madrid: Morata.

Collins, A. \& Halverson, R. (2009).Rethinking education in the age of technology. The digital revolution and schooling in America. New York: Teachers College Press

Cox, M., \& Webb, M. (2004). An investigation of the research evidence relating to ICT pedagogy.London: Becta for DfES.

Cuban, L., Kirpatrick, H. \& Peck, C. (2001). High access and low use of technologies in high school classrooms: explaining an apparent paradox. American Educational Research Journal 38 (4), 813-834 doi: 10.3102/00028312038004813

Drent, M. \& Meelissen, M. (2008). Which factors obstruct or stimulate teacher educators to use ICT innovatively? Computers \& Education, 187-199 doi:10.1016/j.compedu.2007.05.001

Ertmer, P. (1999). Adressing first-and second-order barriers to change: strategies for technology integration. Educational Technology Research and Development, 47 (4), 47 61 doi: 10.1007/BF02299597 
Ertmer, P. (2005). Teacher pedagogical beliefs: the final frontier in our quest for technology integration? Educational Research and Development, 53 (4), 25-39 doi: 10.1007/BF02504683

Ertmer, P.A, Ottenbreit-Leftwich, A.T., Sadik, O., Sendurur, E. \& Sendurur P. (2012). Teacher beliefs and technology integration practices: A critical relationship. Computers \& Education, 59, 423-435. doi:10.1016/j.compedu.2012.02.001

Fisher, C.,Dwyer, D.C., \& Yocam, K. (Eds.). (1996). Education and technology: Reflections on computing in classrooms. San Francisco, Jossey-Bass.

Hadjithoma, C. \& Karagiorgi, Y (2009). The use of ICT in primary schools within emerging communities of implementation. Computers \& Education, 52, 83-91 doi:10.1016/j.compedu.2008.06.010

Hennessy, S, Ruthven, K, \& Brindley, S. (2005). Teacher perspectives on integrating ICT into subject teaching: commitment, constraints, caution and change. Journal of Curriculum Studies, 37 (2), 155-192. doi:10.1080/0022027032000276961

Hermans, R., van Braak, J. \& van Keer, H. (2008). Development of the beliefs about primary education scale: distinguishing a developmental and transmissive dimension. Teaching and Teacher Education, 24, 127-139. doi:10.1016/j.tate.2006.11.007

Hermans, R., Tondeur, J., van Braak, J. \& Valcke, M. (2008). The impact of primary school teachers' educational beliefs on the classroom use computers. Computers \& Education, 51, 1499-1509. doi:10.1016/j.compedu.2008.02.001

Howard, S.K., Chan, A. \& Caputi, P. (2014). More than beliefs: Subject areas and teachers'integration of laptops in secondary teaching. British Journal of Educational Technology, doi: 10.1111/bjet.12139

Inan, F.A. \& Lowther, D.L. (2010). Factors affecting technology integration in K-12 classrooms: a path model. Educational Technology Research and Development, 58 (2), 137-154. doi: 10.1007/s11423-009-9132-y

Iniesta-Bonillo, M.A., Sánchez-Fernández, R. \& Schlesinger, W. (2013). Investigating factors that influence on ICT usage in higher education: a descriptive analysis. International Review on Public and Nonprofit Mark, 10, 163-174 doi:10.1007/s12208-013-0095-7

Jamieson-Proctor, R. , Watson, G. , Finger, G. , Grimbeek, P. \& Burnett, P.C. (2007) Measuring the Use of Information and Communication Technologies (ICTs) in the 
Classroom, Computers in the Schools: Interdisciplinary Journal of Practice, Theory, and Applied Research, 24:1-2, 167-184. doi: 10.1300/J025v24n01_11

Kerlinger, F. N., \& Kaya, E. (1959a). The construction and factor analytic validation of scales to measure attitudes toward education. Educational and Psychological Measurement, 19, 13-29. http://dx.doi.org/10.1177/001316445901900102

Kerlinger, F. N., \& Kaya, E. (1959b). The predICTive validity of scales constructed to measure attitudes toward education. Educational and Psychological Measurement, 19, $305-317$.

doi: 10.1177/001316445901900303

Kim, C., Kim, M.K., Lee, C., Spector, J.M. \& DeMeester, K. (2013). Teacher beliefs and technology integration. Teaching and Teacher Education, 29, 76-85 doi:10.1016/j.tate.2012.08.005

Landis, J. R., \& Koch, G. G. (1977). The measurement of observer agreement for categorical data. Biometrics, 159-174. doi: 10.2307/2529310

Liu, S. (2011). Factors related to pedagogical beliefs of teachers and technology integration. Computers and Education, 56, 1012-1022. doi:10.1016/j.compedu.2010.12.001

López-Íñiguez, G. \& Pozo, J.I. (submitted) Analysis of constructive practice in instrumental music education: Case study with an expert cello teacher

López-Íñiguez, G.; Pozo, J.I. \& De Dios, M.J. (2014). The older, the wiser? Profiles of string instrument teachers with different experience according to their conceptions of teaching, learning and evaluation. Psychology of Music, 42(2), 157-176

doi: $10.1177 / 0305735612463772$

Mama, M. \& Hennessy, S. (2013). Developing a typology of teacher beliefs and practices concerning classroom use of ICT. Computers \& Education, 68, 380-387. doi:10.1016/j.compedu.2013.05.022

Margaryan, A., Littlejohn, A. \& Vojt, G. (2011). Are digital natives a myth or reality? University students'use of digital technologies. Computers \& Education, 56, 429-440 doi:10.1016/j.compedu.2010.09.004

Monereo, C. (2004). The virtual construction of the mind: the role of educational psychology. Interactive Educational Multimedia, 9, 32-47

Mumtaz, S. (2000). Factors affecting teachers'use of information and communications technology: a review of the literature. Journal of Information Technology for Teacher Education, 9 (3), 319-342. doi: 10.1080/14759390000200096 
Nespor, J. (1987). The role of beliefs in the practice of teaching. Journal of Curriculum Studies, 19, 317-328. doi: 10.1080/0022027870190403

Niederhauser, D.S. \& Stoddart, T. (2001). Teacher's instructional perspectives and use of educational software. Teaching and Teacher Education, 17, 15-31 doi:10.1016/S0742-051X(00)00036-6

Olson, D. R., \& Bruner, J. S. (1996). Folk psychology and folk pedagogy. In D. R. Olson \& N. Torrance (Eds.), Handbook of education and human development: New models of learning, teaching, and schooling (pp. 9-27). Cambridge, MA: Blackwell.

Pajares, M.F. (1992). Teacher beliefs and educational research: Cleaning up a messy construct. Review of Educational Research, 62, 307-332 doi: $10.3102 / 00346543062003307$

Peek, S., Wouters, E., van Hoof, J. Luijkx, K., Boeije, H. \& Vrijhoef, H. (2014). Factors influencing acceptance of technology for aging in place: A systematic review. International Journal of Medical Informatics, 83, 235-248 http://dx.doi.org/doi:10.1016/j.ijmedinf.2014.01.004

Pelgrum, W.J. (2001). Obstacles to the integration of ICT in education: results from a worldwide educational assessment. Computers \& Education, 37, 163-178 doi:10.1016/S0360-1315(01)00045-8

Pozo, J.I. (2008). Aprendices y maestros. La psicología cognitiva del aprendizaje. Madrid: Alianza Editorial.

Pozo, J.I. \& Postigo, Y. (2000). Los procedimientos como contenidos escolares. Barcelona: Edebé

Pozo, J. I., Scheuer, N., Pérez Echeverría, M. del P., Mateos, M., Martín, E., \& de la Cruz, M. (Eds.) (2006). Nuevas formas de pensar la enseñanza y el aprendizaje. Las concepciones de profesores y alumnos. Barcelona: Graó.

Prestridge, S. (2012). The beliefs behind the teacher that influences their ICT practices. Computers \& Education 58, 449-458 doi:10.1016/j.compedu.2011.08.028

Richardson, V. (2003). Pre-service teachers'beliefs. En J.Raths y A.C. McAninch (Eds.), Teacher beliefs and clasroom performance: The impact of teacher education (pp. 1-22). Greenwich, CT: Information Age Publishing.

Salomon, G., Perkins, D. \& Globerson, T. (1991). Partners in cognition: extending human intelligences with inteligent technologies. Educational Researcher , 20 (3), 2-9 doi: 10.3102/0013189X020003002 
Sang, G. Valcke, M. van Braak, J. \& Tondeur, J. (2010). Student teachers'thinking processes and ICT integration: PredICTors of prospective teaching behaviours with educational technology. Computers \& Education, 54, 103-112 doi:10.1016/j.compedu.2009.07.010

Schön, D. (1987). Educating the reflective practitioner. San Francisco, CA: Jossey-Bass.

Sigalés, C., Mominó, J.Ma., Meneses, J. \& Badia, A. (2008). La integración de internet en la educación escolar española: situación actual y perspectivas de futuro. Informe de investigación elaborado con la colaboración de la UOC y Fundación Telefónica.

Silvernail, D., \& Gritter, A. (2005). Maine's middle school laptop program: Creating better writers. Gorham, ME: Maine Education Policy Research Institute.

Squires, D. \& McDougall, L.S. (1994). Choosing and Using Educational Software: a teacher's guide. Londres: Falmer Press.

Starkey, L. (2009). Teacher's pedagogical reasoning and action in the digital age. Teachers and Teaching: theory and practice, 16 (2), 233-244. doi: 10.1080/13540600903478433

Tamim,R.M., Borokhovski, E., Abrami, P.C. \& Schmid, R.F (2011). What forty years of research says about the impact of technology on learning: a second- order meta-analysis and validation study, Review of Educational Research, 81 (1), 4-28 doi: $10.3102 / 0034654310393361$

Teo, T., Chai, C. S., Hung, D., \& Lee, C. B. (2008). Beliefs about teaching and uses of technology among pre-service teachers. Asia-Pacific Journal of Teacher Education, 36(2), 163-174. doi: 10.1080/13598660801971641

Thompson, P. (2013). The digital natives as learners: Technology use patterns and approaches to learning. Computers \& Education, 65, 12-33 doi:10.1016/j.compedu.2012.12.022

Tondeur, J., van Braak, J. \& Valcke, M. (2007). Towards a typology of computer use in primary education. Journal of Computer Assisted Learning, 23, 197-206

Tondeur, J., Hermans, R., van Braak, J. \& Valcke, M. (2008) Exploring the link between teachers'educational belief profiles and different types of computer use in the classroom. Computers in Human Behaviour, 24, 2541-2553

doi: 10.1111/j.1365-2729.2006.00205.x

Twining, P. (2002). Conceptualising computer use in education: introducing the Computer Practice Framework (CPF). British Educational Research Journal, 28 (1), 95-110 doi: $10.1080 / 01411920120109775$

van Braak, J. (2001). Factors influencing the use of computer mediated communication by teachers in secondary schools. Computers \& Education, 36, 41-57 


\section{doi:10.1016/S0360-1315(00)00051-8}

van Braak, J., Tondeur, J., \& Valcke, M. (2004). Explaining different types of computer use among primary school teachers. European Journal of Psychology of Education, 19, 407-422.doi: 10.1007/BF03173218

Vekiri, I. (2010). Boys'and girls 'ICT beliefs: Do teachers matter? Computers and Education, 55, 16-23 doi:10.1016/j.compedu.2009.11.013

Vekiri, I. \& Chronaki, A. (2008). Gender issues in technology use: Perceived social support, computer self-efficacy and value beliefs, and computer use beyond school. Computers and Education, 51, 1392-1404 doi:10.1016/j.compedu.2008.01.003

Volman, M., van Eck, E., Heemskerk, I., \& Kuiper, E. (2005). New technologies, new differences. Gender and etnic differences in pupils' use of ICT in primary and secondary education. Computers \& Education, 45, 35-55. doi:10.1016/j.compedu.2004.03.001

Zhao, Y., \& Cziko, G. A. (2001). Teacher Adoption of Technology: A Perceptual Control Theory Perspective. Journal of Technology and Teacher Education, 9(1), 5-30. 
A continuación le vamos a realizar una serie de preguntas donde nos interesamos por sus concepciones en relación a las Tecnologías de la Información y la Comunicación (de ahora en adelante TIC) y su impacto educativo en los procesos de enseñanza y aprendizaje. La información es anónima y el uso de la misma exclusivamente con fines académicos. Muchas gracias por su colaboración.

\section{DATOS PERSONALES}

1-Edad:

2-Sexo:

3-¿Qué estudios ha cursado?

4-Colegio en el que trabaja actualmente:

5-¿Cuántos años hace que se dedica a la docencia?:

6-¿Qué materias imparte actualmente y en qué cursos?:

7-¿Utiliza las TIC en el contexto de las asignaturas que imparte? ¿En cuáles?:
8-¿Con qué frecuencia las utiliza? (indique la frecuencia de uso en relación a cada una de las asignaturas):

\begin{tabular}{|l|l|l|l|l|}
\hline Materia & $\begin{array}{l}\text { Diaria- } \\
\text { mente }\end{array}$ & $\begin{array}{l}\text { Semanal- } \\
\text { mente }\end{array}$ & $\begin{array}{l}\text { Mensual- } \\
\text { mente }\end{array}$ & $\begin{array}{l}\text { Anual- } \\
\text { mente }\end{array}$ \\
\hline & & & & \\
\hline & & & & \\
\hline & & & & \\
\hline
\end{tabular}

9-¿Cuántos años hace que utiliza las TIC en el contexto educativo?:

10- ¿Utiliza las TIC en el contexto educativo por voluntad propia o porque son las directrices del centro?

11-¿Qué tipo de tecnologías utiliza en el contexto de la/s materia/s que impartes (tanto hardware como software)? 
1-Según su opinión, ¿cree que el impacto provocado por las TIC está cambiando las formas de enseñar y aprender? En caso afirmativo, ¿de qué manera lo están haciendo?

2-A continuación describa los 3 usos de las TIC que considere más importante en el contexto de alguna de las asignaturas que imparta (escoja usted mismo las materias deseadas), atendiendo a los criterios que le proponemos a continuación:

\section{$\underline{\text { Actividad } 1}$}

Materia y curso:

Descripción:

Rol desempeñado por el docente y los alumnos:

Objetivo de aprendizaje deseado:

Posibles problemas de aprendizaje que puedan surgir en sus alumnos y su reacción como docente frente a los mismos: 
$\underline{\text { Actividad } 2}$

Materia y curso:

Descripción:

Rol desempeñado por el docente y los alumnos:

Objetivo de aprendizaje deseado:

Posibles problemas de aprendizaje que puedan surgir en sus alumnos y su reacción como docente frente a los mismos: 


\section{$\underline{\text { Actividad } 3}$}

Materia y curso:

Descripción:

Rol desempeñado por el docente y los alumnos:

Objetivo de aprendizaje deseado:

Posibles problemas de aprendizaje que puedan surgir en sus alumnos y su reacción como docente frente a los mismos:

¡Muchas gracias por su colaboración! 